\title{
BUDYNKI O NISKIM ZUŻYCIU ENERGII (NZEB) W ASPEKCIE ARCHITEKTONICZNO-BUDOWLANYM
}

DOI: 10.37660/integr.2020.6.2.6

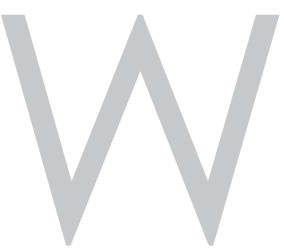

edług krajowego planu mającego na celu zwiększenie liczby budynków o niskim zużyciu energii' budynek o niskim zużyciu energii (NZEB) to taki, który spełnia wymagania związane z oszczędnościa energii i izolacyjnościa, zawarte w przepisach techniczno-użytkowych, o których mowa w art. 7 ust. 1 pkt 1 ustawy Prawo budowlane2, tj. w szczególności dział X oraz załącznik 2 do rozporzadzenia, obowiązujące od 31 grudnia 2020 roku (w przypadku budynków zajmowanych przez władze publiczne oraz będących ich własnościa od 1.01.2019 r.) $)^{3}$.

Zasadnicza zmiana rozporządzenia ${ }^{4}$ w zakresie ochrony cieplnej budynków jest zmiana wartości maksymalnych współczynników przenikania ciepła $U_{c(m a-}$ ${ }_{x)} / U_{(\max )}$. Zaostrzeniu uległy wymagania czastkowe w zakresie izolacyjności cieplnej ścian zewnętrznych, dachów, podłóg oraz okien i drzwi. Ponadto nie ma już znaczenia typ przegrody (wielo- czy jednowarstwowa) oraz przeznaczenie obiektu (mieszkalny, użyteczności publicznej, magazynowy, gospodarczy itp.). Wprowadzone zmiany $w$ rozporzadzeniu ${ }^{5}$ w zakresie oszczędności energii i ochrony cieplnej dołycza jednoczesnego spełnienia dwóch wymagań w zakresie: współczynnika przenikania ciepła $U\left[\mathrm{~W} /\left(\mathrm{m}^{2} \cdot \mathrm{K}\right)\right]-\left(U_{\mathrm{c}} / U \leq U_{\mathrm{c}(\max )} / U_{(\max )}\right)$ dla pojedynczych przegród budynku oraz wskaźnika zapotrzebowania na nieodnawialna energię pierwotna EP [kWh/(m² rok)] - (EP $\leq \mathrm{EP}_{(\max )}$ dla całego budynku. Wymagania minimalne, o których mowa w ust. 1 rozporzadzenia ${ }^{6}$, uznaje się za spełnione dla budynku podlegajacego przebudowie, jeżeli przegrody oraz wyposażenie techniczne budynku podlegajace przebudowie odpowiadaja przynajmniej wymaganiom izolacyjności cieplnej określonym w załączniku nr 2 do rozporządzenia7: $U_{c} / U \leq U_{c(\text { max })} / U_{(\text {max })}$.

W pracy przedstawiono charakterystykę budynków o niskim zużyciu energii (NZEB) w aspekcie wymagań prawnych dotyczących oszczędności energii oraz ochrony cieplno-wilgotnościowej. W części obliczeniowej pracy zestawiono wyniki

drinż. Krzyszłof Pawłowski, prof. uczelni, https://orcid.org/0000-0002-6738-5764,

mgr inż. arch. Łukasz Lewandowski, https://orcid.org/0000-0003-1771-3456, Katedra Budownictwa Zrównoważonego, Wydział Budownictwa, Architektury i Inżynierii Środowiska, Uniwersyłet Technologiczno-Przyrodniczy im. Jana i Jędrzeja Śniadeckich w Bydgoszczy

1 Uchwała Rady Ministrów z dnia 22 czerwca 2015 r. w sprawie przyjęcia „Krajowego planu majacego na celu zwiększenie liczby budynków o niskim zużyciu energii".

2 Ustawa z dnia 7 lipca 1994 r. - Prawo budowlane (Dz.U. z 2013 r. poz. 1409, z późn.zm.).

3 Rozporzadzenie Ministra Infrastruktury i Budownictwa z dnia 14 listopada 2017 r. zmieniające rozporzadzenie w sprawie warunków technicznych, jakim powinny odpowiadać budynki i ich usytuowanie (Dz.U. z 2017 r. poz. 2285).

4 Ibidem.

5 Ibidem.

Ibidem.

Ibidem. 
analizy numerycznej połączenia ściany zewnętrznej z oknem, ocieplonej od strony zewnętrznej i wewnętrznej, oraz zaproponowano rozwiazania materiałowe przegród przeźroczystych, dachów zielonych, słonecznych dachów zielonych oraz fasad wentylowanych.

\section{CHARAKTERYSTYKA BUDYNKÓW O NISKIM ZUŻYCIU ENERGII}

Budownictwo zrównoważone to budownictwo przyjazne środowisku naturalnemu i człowiekowi, kłóre realizuje zasady zrównoważonego rozwoju w wyniku oddziaływania uwzględniającego metody oszczędzania zasobów naturalnych oraz przeciwdziałania zanieczyszczeń środowiska. Na podstawie prowadzonych analiz i obliczeń określono podstawowe grupy czynników w zakresie klasyfikacji budynków o niskim zużyciu energii (NZEB):

- architektura budynku: usytuowanie budynku względem stron świata, zróżnicowana roślinność na działce budowlanej, zwarta bryła budynku (minimalny współczynnik kszłałtu A/V), wielkość i usytuowanie przegród przeźroczystych, rozmieszczenie pomieszczeń wewnątrz budynku, geometria dachu;

- rozwiqzania konstrukcyjno-materiałowe przegród zewnętrznych i ich złączy (elementów obudowy budynku): stosowanie materiałów wysokiej jakości i innowacyjnych materiałów termoizolacyjnych (np. płyły z pianek poliuretanowych PIR, PUR, aerożele, izolacje próżniowe, izolacje transparentne), stosowanie nowoczesnych rozwiqzań konstrukcyjno-materiałowych przegród zewnętrznych (np. dachy zielone, słoneczne dachy zielone, ściany zielone, fasady wentylowane, przegrody przeźroczyste z zastosowaniem przesłon przeciwsłonecznych w zakresie ochrony pomieszczeń przed przegrzewaniem w okresie letnim), szkoła projektowania złączy budowlanych w aspekcie cieplno-wilgotnościowym przy zastosowaniu programów numerycznych; minimalizacja strat ciepła przez przegrody w polu jednowymiarowym (1D) i dwuwymiarowym (2D) oraz ryzyka występowania krytycznej wilgotności powierzchniowej oraz kondensacji międzywarstwowej;

- rodzaj i sprawność systemu wentylacji: wentylacja hybrydowa lub mechaniczna z odzyskiem ciepła, wentylacja mechaniczna z gruntownym wymiennikiem ciepła, wspomaganie istniejących systemów wentylacji naturalnej - stosowanie kominów słonecznych, wysoka sprawność systemów powyżej 70\%;

- rodzaj i sprawność systemów instalacji c.o. i c.w.u.: wysoka sprawność systemów powyżej 70\%, wspomagania systemów c.o. i c.w.u. odnawialnymi źródłami energii (energia słoneczna, energia wiatrowa, energia geotermalna);

- integralne zarządzanie budynkiem w zakresie produkcji energii oraz systemowe zarzadzanie energia w budynku - BMS.

Od kilkunastu lat przepisy prawne związane z procesami projektowania, wznoszenia i eksploatacji budynków o niskim zużyciu energii (NZEB) wymuszaja takie rozwiqzania technologiczne i organizacyjne, w wyniku których nowo wznoszone budynki zużywaja w trakcie eksploatacji coraz mniej energii na ogrzewanie, wentylację i przygotowanie ciepłej wody użytkowej. Zmiany maksymalnej wartości współczynnika przenikania ciepła $U_{\max }$ (dawniej $k_{\max }$ ) wpływaja na wielkość zużycia energii w trakcie eksploatacji budynków. Niestety przepisy prawne w tym zakresie nie reguluja wymagań dotyczacych ograniczenia strat ciepła przez złacza budowlane - mostki cieplne, ponieważ nie określono wartości granicznych 
np. w zakresie maksymalnych wartości liniowego współczynnika przenikania ciepła $\Psi_{\text {max. }}[\mathrm{W} /(\mathrm{m} \cdot \mathrm{K})]$.

Zasadne staje się przywrócenie obliczania obiekływnych wartości współczynników $U_{c} / U$ poszczególnych przegród budynku z uwzględnieniem przepływów dwuwymiarowych (2D), a dla przegród w kontakcie z gruntem - trójwymiarowych (3D). Obniżanie wartości granicznych współczynników przenikania ciepła $U_{c(m a-}$ ${ }_{x)} / U_{(\max )}$ bez uwzględniania przepływów ciepła w polu (2D) i (3D) (czyli mostków cieplnych) powoduje rzeczywiste dopuszczenie większych strat ciepła przez przegrody budowlane i ich złącza.

Zastosowanie odpowiedniego materiału termoizolacyjnego pozwala na osiagnięcie niskich wartości współczynnika przenikania ciepła $U\left[\mathrm{~W} /\left(\mathrm{m}^{2} \cdot \mathrm{K}\right)\right]$ pełnej przegrody i liniowego współczynnika przenikania ciepła $\Psi[\mathrm{W} /(\mathrm{m} \cdot \mathrm{K})]$ oraz minimalizację ryzyka występowania kryłycznej wilgotności powierzchniowej (kondensacji powierzchniowej) i kondensacji międzywarstwowej. Przed wyborem odpowiedniego materiału do izolacji cieplnej, w aspekcie projektowania nowych obiektów lub modernizacji budynków istniejących, należy zwrócić uwagę na następujące ich właściwości: współczynnik przewodzenia ciepła $(\lambda[\mathrm{W} /(\mathrm{m} \cdot \mathrm{K})]$, gęstość objętościowa, izolacyjność akustyczna, przepuszczalność pary wodnej, współczynnik oporu dyfuzyjnego $\mu[-]$, wrażliwość na czynniki biologiczne i chemiczne oraz ochronę przeciwpożarową.

Określenie jakości energetycznej danego budynku można uzyskać poprzez obliczenie trzech wyznaczników oraz ich korelacji: wskaźnika zapotrzebowania na energię użytkowa EU [kWh/( $\left.\left.\mathrm{m}^{2} \cdot \mathrm{K}\right)\right]$, wskaźnika zapotrzebowania na energię końcowa EK $\left[\mathrm{kWh} /\left(\mathrm{m}^{2} \cdot \mathrm{K}\right)\right]$ i wskaźnika zapotrzebowania na nieodnawialna energię pierwotna EP $\left[\mathrm{kWh} /\left(\mathrm{m}^{2} \cdot \mathrm{K}\right)\right]$. Na podstawie ich wartości analizowany budynek jest przypisywany do klasy energetycznej (A-G).

Określajac energochłonność budynku o niskim zużyciu energii (NZEB), należy uwzględnić także sprawności systemów instalacyjnych budynku wynikające z: regulacji i wykorzystania ciepła w przestrzeni ogrzewanej $\left(\eta_{H, e}\right)$, przesyłu ciepła ze źródła ciepła do przestrzeni ogrzewanej $\left(\eta_{H, d}\right)$, akumulacji ciepła w elementach pojemnościowych systemu ogrzewania $\left(\eta_{H, s}\right)$, wytwarzania ciepła z nośnika energii lub energii dostarczanych do źródła ciepła $\left(\eta_{\mathrm{H}, \mathrm{g}}\right)$. Instalacja grzewcza w budynku musi spełniać wymagania przepisów techniczno-budowlanych, a także powinna uwzględniać wiedzę techniczna z zakresu rozwiąań energooszczędnych. Projektowany system powinien być systemem wysokosprawnym. Należy zaplanować wysokosprawne źródła ciepła, dołożyć wszelkich starań w celu obniżenia strat na przesyle czynnika grzewczego oraz jeśli występuje zbiornik akumulacyjny, straty na akumulacji powinny być minimalne, a także optymalnie dobrać elementy odpowiedzialne za regulację i wykorzystanie ciepła. Maksymalne możliwe sprawności można uzyskać m.in. poprzez: stosowanie kołłów kondensacyjnych, pomp ciepła o wysokim współczynniku efektywności (COP), odpowiednie prowadzenie przewodów rozprowadzajacych czynnik grzejny (zwarta instalacja) oraz ich właściwą izolację cieplna, odpowiednią izolację zbiorników buforowych oraz dobrane do specyfiki ich pracy

8 M. Wesołowska, K. Pawłowski, 2016. Aspekty zwiqzane z dostosowaniem obiektów istniejacych do standardu budownictwa energooszczędnego. Agencja Reklamowa TOP, Włocławek. 
i użyłkowania sterowanie ładowaniem i rozładowaniem, niskołemperaturowe systemy grzejne płaszczyznowe, grzejnikowe lub mieszane, stosowanie wysokosprawnych pomp pomocniczych charakteryzujacych się niskim poborem mocy (skutkujące małym zużyciem energii pomocniczej).

Wartość wskaźnika rocznego zapotrzebowania na nieodnawialna energię pierwotna (EP) określa w wielu przypadkach efektywność całkowita budynku. Dołyczy energii zawartej w źródłach, w tym paliwach i nośnikach, niezbędnej do pokrycia zapotrzebowania na energię końcowa, z uwzględnieniem dodatkowych nakładów na dostarczenie tej energii do granicy budynku. Wartość współczynnika nakładu nieodnawialnej energii pierwotnej na wytworzenie i dostarczenie nośnika energii lub energii dla systemów technicznych $w_{i}$ przyjmuje się na podstawie danych udostępnionych przez dostawcę tego nośnika energii lub energii. Uzyskanie niskich wartości wskaźnika EP wskazuje na nieznaczne zapotrzebowanie i tym samym wysokq efektywność energetyczna budynku. Na stronach internetowych niektórzy dostawcy ciepła zamieszczają wartości wskaźnika nakładu nieodnawialnej energii pierwotnej $w_{i}$. Jednak w przypadku braku takich danych przyjmuje się wartości współczynnika $w_{i}$ na podstawie danych w rozporzadzeniu?.

\section{KSZTAKTOWANIE UKKADU WARSTW MATERIAKOWYCH ELEMENTÓW OBUDOWY BUDYNKÓW O NISKIM ZUŻYCIU ENERGII}

Budynek stanowi zbiór przegród budowlanych i ich złączy o indywidualnym charakterze fizykalnym i poddany jest oddziaływaniu środowiska zewnętrznego i wewnętrznego. W wielu przypadkach analiza przegród i złączy budowlanych w aspekcie konstrukcyjno-materiałowym i technologii wykonania nie budzi zastrzeżeń na etapie projektowania. Natomiast znajomość ich parametrów fizykalnych, zwiqzanych z wymiana ciepła i wilgoci, pozwala na uniknięcie wielu wad korozyjnych i fizykalnych.

Efektywne zastosowanie materiału termoizolacyjnego (odpowiednia grubość i usytuowanie) umożliwia uzyskanie następujących istotnie ważnych parametrów fizykalnych przegród zewnętrznych i złączy budynku o niskim zużyciu energii (NZEB):

- współczynnik przenikania ciepła $U\left(U_{1 D}\right)\left[\mathrm{W} /\left(\mathrm{m}^{2} \cdot \mathrm{K}\right)\right]$ dotyczacy strat ciepła przez płaska przegrodę na poziomie niższym od wartości maksymalnych $U_{c(\max )} / U_{(\max )}$ podanych w przepisach prawnych,

- liniowy współczynnik przenikania ciepła $\Psi[\mathrm{W} /(\mathrm{m} \cdot \mathrm{K})]$ dołyczący strat ciepła wynikajacych z występowania liniowych mostków cieplnych,

- temperatura minimalna na wewnętrznej powierzchni przegrody $t_{\text {si,min }}\left[{ }^{\circ} \mathrm{C}\right]$ w miejscu występowania mostków cieplnych (2D) i (3D),

- czynnik temperaturowy $f_{\text {Rsi.(2D) }}$ i $f_{\text {Rsi.(3D) }}$ określony na podstawie temperatury minimalnej na wewnętrznej powierzchni przegrody $t_{\text {si,min }}\left[{ }^{\circ} \mathrm{C}\right] \mathrm{w}$ miejscu występowania mostków cieplnych (2D) i (3D) na poziomie wyższym niż war-

\footnotetext{
9 Rozporzadzenie Ministra Infrastruktury i Rozwoju w sprawie metodologii obliczania charakterystyki energetycznej budynku i lokalu mieszkalnego lub części budynku stanowiacej samodzielna całość techniczno-użyłkowa oraz sposobu sporządzania i wzorów świadectw charakterystyki energetycznej (Dz.U. z 2015 r., poz. 376).
} 
tość kryłyczna przy określonych parametrach powietrza zewnętrznego i wewnętrznego.

W celu poszukiwania poprawnego rozwiqzania układu materiałowego spełniającego obowiązujace wymagania dla budynku o niskim zużyciu energii (NZEB) należy wykonać szczegółowe obliczenia parametrów fizykalnych złączy przegród zewnętrznych w kilku wariantach obliczeniowych. W pracy rozpatrywano połaczenie ściany zewnętrznej z oknem w przekroju przez ościeżnicę przy zróżnicowanym usytuowaniu ocieplenia w następujących wariantach:

- wariant I (rys. 1): ściana zewnętrzna z cegły pełnej gr. $25 \mathrm{~cm}$ ( $\lambda=0,77 \mathrm{~W} /$ $(\mathrm{m} \cdot \mathrm{K}))$; tynk gipsowy gr. 1,5 cm $(\lambda=0,40 \mathrm{~W} /(\mathrm{m} \cdot \mathrm{K}))$; stolarka okienna: przypadek A - o współczynniku przenikania ciepła okna $U_{w}=1,75 \mathrm{~W} /\left(\mathrm{m}^{2} \cdot \mathrm{K}\right)$, przypadek $B-U_{w}=0,86 \mathrm{~W} /\left(\mathrm{m}^{2} \cdot \mathrm{K}\right)$;

- wariant II (rys. 1): ściana zewnętrzna z cegły pełnej gr. $25 \mathrm{~cm}(\lambda=0,77 \mathrm{~W} /(\mathrm{m} \cdot \mathrm{K}))$; tynk gipsowy gr. $1,5 \mathrm{~cm}(\lambda=0,40 \mathrm{~W} /(\mathrm{m} \cdot \mathrm{K}))$; izolacja termiczna od zewnątrz: płyty rezolowe gr. 10 i $15 \mathrm{~cm}(\lambda=0,021 \mathrm{~W} /(\mathrm{m} \cdot \mathrm{K}))$; stolarka okienna $U_{\mathrm{w}}=0,86 \mathrm{~W} /$ $\left(\mathrm{m}^{2} \cdot \mathrm{K}\right)$; bez węgarka;

- wariant III (rys. 3): ściana zewnętrzna z cegły pełnej gr. $25 \mathrm{~cm}(\lambda=0,77 \mathrm{~W} /$ $(m \cdot K))$; tynk gipsowy gr. 1,5 cm $(\lambda=0,40 \mathrm{~W} /(\mathrm{m} \cdot \mathrm{K}))$; izolacja termiczna od zewnątrz: płyły rezolowe gr. 10 i $15 \mathrm{~cm}(\lambda=0,021 \mathrm{~W} /(\mathrm{m} \cdot \mathrm{K}))$; stolarka okienna $U_{w}=0,86 \mathrm{~W} /\left(\mathrm{m}^{2} \cdot \mathrm{K}\right)$; z węgarkiem (ocieplenie zachodzi na ościeżnicę $-4 \mathrm{~cm}$ );

- wariant IV (rys. 4): ściana zewnętrzna z cegły pełnej gr. $25 \mathrm{~cm}(\lambda=0,77 \mathrm{~W} /$ $(\mathrm{m} \cdot \mathrm{K}))$; tynk gipsowy gr. 1,5 cm $(\lambda=0,40 \mathrm{~W} /(\mathrm{m} \cdot \mathrm{K}))$; izolacja termiczna od wewnątrz: płyty rezolowe gr. 10 i $15 \mathrm{~cm}(\lambda=0,021 \mathrm{~W} /(\mathrm{m} \cdot \mathrm{K}))$; stolarka okienna $\mathrm{U}_{\mathrm{w}}=0,86 \mathrm{~W} /\left(\mathrm{m}^{2} \cdot \mathrm{K}\right)$; bez węgarka;

- wariant $\vee$ (rys. 5): ściana zewnętrzna z cegły pełnej gr. $25 \mathrm{~cm}(\lambda=0,77 \mathrm{~W} /$ $(\mathrm{m} \cdot \mathrm{K}))$; tynk gipsowy gr. 1,5 cm $(\lambda=0,40 \mathrm{~W} /(\mathrm{m} \cdot \mathrm{K}))$; izolacja termiczna od wewnątrz: płyty rezolowe gr. 10 i $15 \mathrm{~cm}(\lambda=0,021 \mathrm{~W} /(\mathrm{m} \cdot \mathrm{K}))$; stolarka okienna $U_{w}=0,86 \mathrm{~W} /\left(\mathrm{m}^{2} \cdot \mathrm{K}\right)$; z węgarkiem (ocieplenie zachodzi na ościeżnicę $-4 \mathrm{~cm}$ ).

Na rysunkach 1-5 przedstawiono graficzne wyniki symulacji komputerowej analizowanych złączy przy zastosowaniu programu komputerowego TRISCO, a w tabeli 1 zestawiono wyniki przeprowadzonych obliczeń.

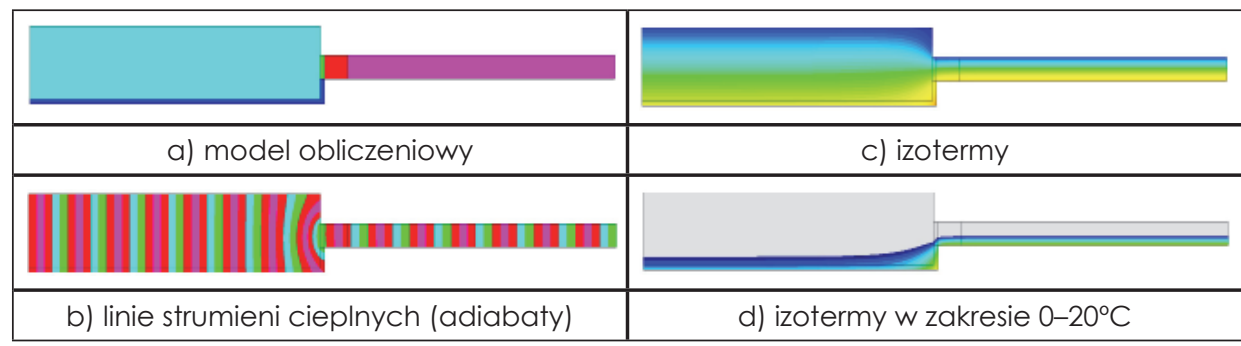

Rys. 1. Przykładowe graficzne przedstawienie wyników symulacji komputerowej dla połaczenia ściany zewnętrznej (bez ocieplenia) z oknem w przekroju przez ościeżnicę (opracowanie własne)

Fig. 1. Exemplary graphics of computer simulation results for external wall joint (without insulation) with a window in section through the casing (own study) 


\begin{tabular}{|c|c|}
\hline & \\
\hline a) model obliczeniowy & \\
\hline & \\
\hline & \\
\hline b) linie strumieni cieplnych (adiabaty) & C) izotermy \\
\hline
\end{tabular}

Rys. 2. Przykładowe graficzne przedstawienie wyników symulacji komputerowej dla połaczenia ściany zewnętrznej (z ociepleniem od zewnatrz) z oknem w przekroju przez ościeżnicę bez węgarka (opracowanie własne)

Fig. 2. Exemplary graphics of computer simulation results for external wall joint (with outside insulation) with a window in section through the casing without nib (own study)

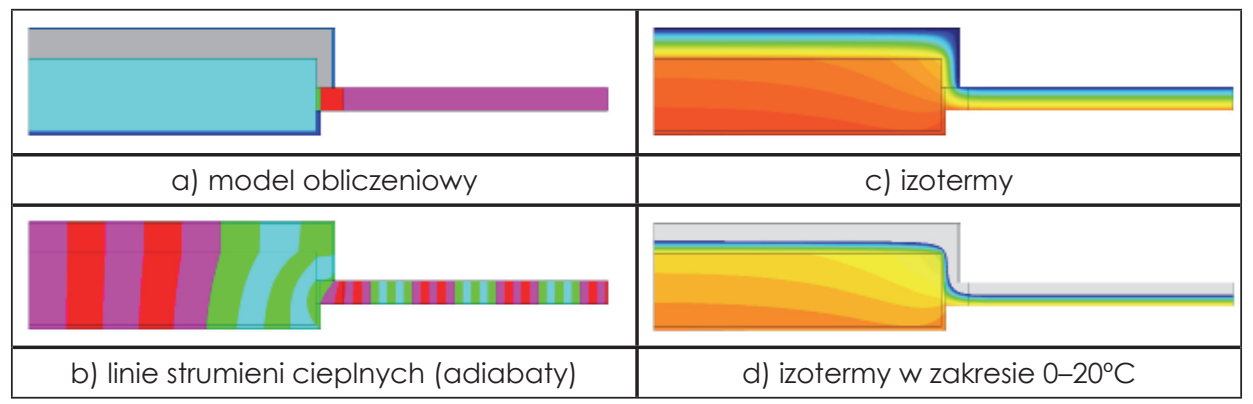

Rys. 3. Przykładowe graficzne przedstawienie wyników symulacji komputerowej dla połaczenia ściany zewnętrznej (z ociepleniem od zewnątrz) z oknem w przekroju przez ościeżnicę z węgarkiem (opracowanie własne)

Fig. 3. Exemplary graphics of computer simulation for external wall joint (with outside insulation) with a window in section through the casing with a nib (own study)

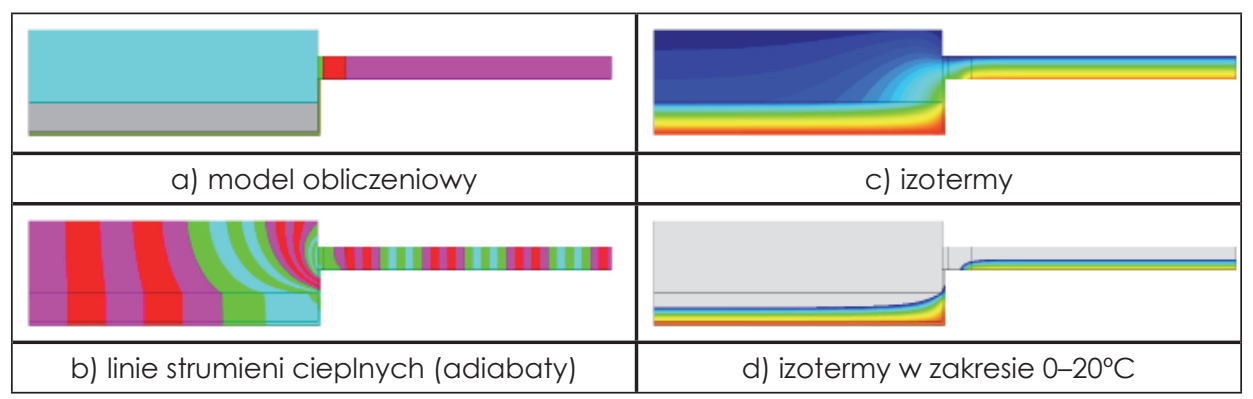

Rys. 4. Przykładowe graficzne przedstawienie wyników symulacji komputerowej dla połaczenia ściany zewnętrznej (z ociepleniem od wewnątrz) z oknem w przekroju przez ościeżnicę bez węgarka (opracowanie własne)

Fig. 4. Exemplary graphics of computer simulation results for external wall joint (with inside insulation) with a window in section through the casing without nib (own study) 


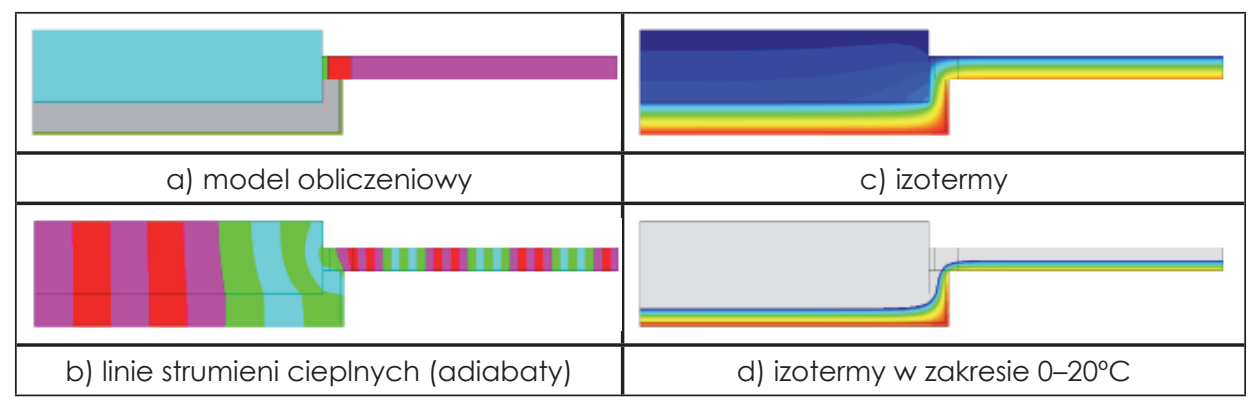

Rys. 5. Przykładowe graficzne przedstawienie wyników symulacji komputerowej dla połaczenia ściany zewnętrznej (z ociepleniem od wewnątrz) z oknem w przekroju przez ościeżnicę z węgarkiem (opracowanie własne)

Fig. 5. Exemplary graphics of computer simulation results for external wall joint (with inside insulation) with a window in section through the casing with nib (own study)

Dla ww. wariantów określono parametry fizykalne przy zastosowaniu programu komputerowego TRISCO, przyjmując następujące założenia:

- modelowanie złączy wykonano zgodnie z zasadami przedstawionymi w PN-EN ISO 10211:2008

- opory przejmowania ciepła $\left(\mathrm{R}_{\mathrm{si}^{\prime}} \mathrm{R}_{\mathrm{se}}\right)$ przyjęto zgodnie z PN-EN ISO 6946:200811 przy obliczeniach strumieni cieplnych oraz wg PN-EN ISO 13788:2003'2 przy obliczeniach rozkładu temperatur i czynnika temperaturowego $f_{\text {Rsi(2D)' }}$

- temperatura powietrza wewnętrznego $t_{i}=20^{\circ} \mathrm{C}$ (pokój dzienny), temperatura powietrza zewnętrznego $t_{\mathrm{e}}=-20^{\circ} \mathrm{C}$ (III strefa),

- wartości współczynnika przewodzenia ciepła materiałów budowlanych $\lambda[\mathrm{W} /$ $(\mathrm{m} \cdot \mathrm{k})$ ] przyjęto na podstawie tabel w pracy ${ }^{13}$.

Na podstawie przeprowadzonych obliczeń (tabela 1) można stwierdzić, że analizowane złącza generuja dodatkowe straty ciepła określone m.in. w postaci liniowego współczynnika przenikania ciepła $\Psi_{i}[\mathrm{~W} /(\mathrm{m} \cdot \mathrm{K})]$ oraz obniżenie temperatury na wewnętrznej powierzchni przegrody $\left.t_{\text {simin }} .{ }^{\circ} \mathrm{C}\right]$. Parametry fizykalne złączy ścian zewnętrznych budynku zależa od usytuowania i grubości materiału termoizolacyjnego. Należy zwrócić uwagę, że ocieplenie połączenia ściany zewnętrznej z oknem bez węgarka powoduje znacznie wyższe dodatkowe straty ciepła $\left(\Phi, \Psi_{i}\right)$ oraz obniżenie temperatury na wewnętrznej powierzchni przegrody $\left(t_{\text {si,min. }}, f_{\text {Rsi.(2D) }}\right)-$ tabela 1. Takie rozwiqzanie powoduje ryzyko występowania kryłycznej wilgotności powierzchniowej (rozwój pleśni i grzybów pleśniowych), kondensacji międzywarstwowej oraz zwiększenie ilości energii koniecznej do ogrzania pomieszczeń o żqdanej temperaturze.

10 PN-EN ISO 10211:2008 Mostki cieplne w budynkach. Strumienie ciepła i temperatury powierzchni. Obliczenia szczegółowe.

11 PN-EN ISO 6946:2008 Komponenty budowlane i elementy budynku. Opór cieplny i współczynnik przenikania ciepła. Metoda obliczania.

12 PN-EN ISO 13788:2003 Cieplno-wilgotnościowe właściwości komponentów budowlanych i elementów budynku. Temperatura powierzchni wewnętrznej umożliwiająca uniknięcie kryłycznej wilgotności powierzchni wewnętrznej kondensacji. Metody obliczania.

${ }^{13}$ K. Pawłowski, 2016. Projekłowanie przegród zewnętrznych w świetle aktualnych warunków technicznych dotyczacych budynków. Obliczenia cieplno-wilgotnościowe przegród zewnętrznych i ich złączy. Grupa Wydawnicza Medium, Warszawa. 
Tabela 1. Wyniki obliczeń parametrów fizykalnych analizowanych złączy ścian zewnętrznych (opracowanie własne)

Table 1. Calculation results of physical parameters for the analyzed joints of external walls (own study)

\begin{tabular}{|c|c|c|c|c|c|}
\hline $\begin{array}{c}\text { Wariant } \\
\text { obliczeniowy }\end{array}$ & $\begin{array}{c}U_{c(s c .)} / U_{w} \\
{\left[\mathrm{~W} /\left(\mathrm{m}^{2} \cdot K\right)\right]}\end{array}$ & $\begin{array}{c}\Phi \\
{[W]}\end{array}$ & $\begin{array}{c}\Psi \\
[\mathrm{W} / \mathrm{m} \cdot \mathrm{K})]\end{array}$ & $\begin{array}{l}\dagger_{\text {si,min. }} \\
{\left[{ }^{\circ} \mathrm{C}\right]}\end{array}$ & $\begin{array}{c}f_{\text {Rsi(2D) }} \\
{[-]}\end{array}$ \\
\hline \multicolumn{6}{|c|}{ wariant I - ściana z cegły gr. $25 \mathrm{~cm}$ bez ocieplenia } \\
\hline I A & $1,88 / 1,75$ & 149,80 & 0,09 & 5,17 & 0,629 \\
\hline I B & $1,88 / 0,86$ & 113,90 & 0,10 & 5,57 & 0,639 \\
\hline \multicolumn{6}{|c|}{ wariant II - ściana z cegły gr. 25 cm ocieplona od zewnątrz bez węgarka } \\
\hline\|\|$_{(10)}$ & $0,19 / 0,86$ & 57,47 & 0,38 & 10,01 & 0,750 \\
\hline $1{ }_{(15)}$ & $0,13 / 0,86$ & 55,78 & 0,40 & 10,13 & 0,753 \\
\hline \multicolumn{6}{|c|}{ wariant III - ściana z cegły gr. 25 cm ocieplona od zewnątrz z węgarkiem } \\
\hline IIII $(10)$ & $0,19 / 0,86$ & 43,27 & 0,08 & 16,66 & 0,917 \\
\hline III $(15)$ & $0,13 / 0,86$ & 41,10 & 0,08 & 16,98 & 0,925 \\
\hline \multicolumn{6}{|c|}{ wariant IV - ściana z cegły gr. 25 cm ocieplona od wewnątrz bez węgarka } \\
\hline$I V_{(10)}$ & $0,19 / 0,86$ & 52,43 & 0,25 & $-2,49$ & 0,438 \\
\hline IV & $0,13 / 0,86$ & 50,48 & 0,26 & $-2,66$ & 0,434 \\
\hline \multicolumn{6}{|c|}{ wariant V - ściana z cegły gr. $25 \mathrm{~cm}$ ocieplona od wewnq̨trz z węgarkiem } \\
\hline$V_{(10)}$ & $0,19 / 0,86$ & 42,81 & 0,06 & 10,84 & 0,771 \\
\hline$V_{(15)}$ & $0,13 / 0,86$ & 40,58 & 0,07 & 10,79 & 0,770 \\
\hline \multicolumn{6}{|c|}{ 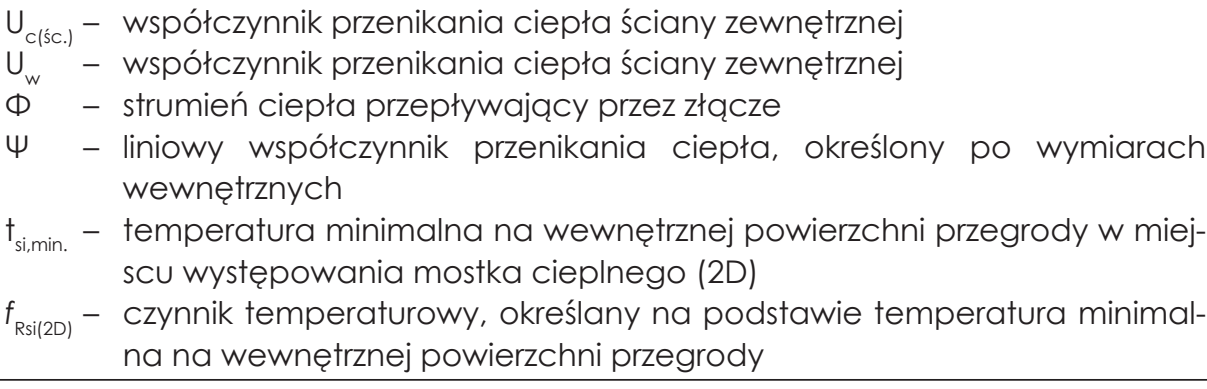 } \\
\hline
\end{tabular}

Złącza ściany zewnętrznej z oknem, ocieplone od zewnątrz, generuja większe straty niż ocieplone od wewnątrz. Wykonanie szczegółowych obliczeń, przy zastosowaniu programu komputerowego, pozwala na uzyskanie miarodajnych wyników parametrów cieplno-wilgotnościowych. Ich wartości zależa od zastosowanego materiału budowlanego (konstrukcyjnego), rodzaju i grubości izolacji cieplnej oraz ukszłałtowania struktury materiałowej analizowanego złącza. Posługiwanie się wartościami przybliżonymi i orientacyjnymi, np. w oparciu o PN-EN ISO 14683:2008'4, staje się nieuzasadnione, ponieważ nie uwzględniaja zmiany układów materiałowych oraz rodzaju i grubości izolacji cieplnej.

W rozpatrywanych wariantach obliczeniowych: I, II, IV i V (tabela 1) występuje obniżenie temperatury na wewnętrznej powierzchni przegrody w miejscu poła-

14 PN-EN ISO 14683:2008 Mostki cieplne w budynkach. Liniowy współczynnik przenikania ciepła. Metody uproszczone i wartości orientacyjne. 
czenia ściany zewnętrznej z oknem. Warunek w zakresie kondensacji powierzchniowej (ryzyka występowania krytycznej wilgotności powierzchniowej): $f_{\text {Rsi.(2D) }} \geq f_{\text {Rsi.(kryt.) }}$ nie został spełniony w związku z tym istnieje ryzyko powstawania pleśni i grzybów pleśniowych. Wartość maksymalna z 12 miesięcy w odniesieniu do lokalizacji (Bydgoszcz) $f_{\text {Ri. (max) }}=f_{\text {Rsi.(kryt.) }}=0,785$ (luty) ${ }^{15}$. Oznacza to, że $w$ każdym miesiącu roku i dla każdych innych wartości temperatur brzegowych dla uniknięcia kondensacji powierzchniowej $f_{\text {Rsi.(2D) }}$ powinien być większy od 0,785.

Spełnienie kryterium w zakresie uniknięcia występowania ryzyka kondensacji powierzchniowej (rozwoju pleśni i grzybów pleśniowych): $f_{\text {Rsi.(2D) }} \geq f_{\text {Rsi.(kryt.) }}$ wymaga określenia wartości $f_{\text {Rsi.(2D) }}$ na podstawie temperatury minimalnej na wewnętrznej powierzchni przegrody $w$ miejscu mostka cieplnego (2D) $t_{\text {si,min. }}\left[{ }^{\circ} \mathrm{C}\right]$ oraz wartości $f_{\text {Rsi.(kryt.) }}$ uwzględniajacej parametry powietrza wewnętrznego i zewnętrznego (wilgotność i temperatura powietrza). Według normy PN-EN ISO 13788:2003 ${ }^{16}$ Czynnik temperaturowy $f_{\text {Rsi(kryt.) }}$ oblicza się lub przyjmuje w zależności od zastosowanego w budynku rodzaju wentylacji (wentylacja grawitacyjna - dominujacca w budownictwie mieszkaniowym lub wentylacja mechanicznej, będąca często składnikiem systemów klimatyzacyjnych, pozwalających w prawie dowolny sposób kształtować właściwości mikroklimatu wnętrz).

Dobór odpowiednich parametrów stolarki okiennej (przenikanie energii słonecznej i ochrona przed utrata ciepła), wpływajacych na mikroklimat wnętrza, powinien następować po przeanalizowaniu warunków klimatycznych, jak i wzajemnego położenia budynków względem stron świata.

Według załącznika 2 rozporzadzenia ${ }^{17}$ we wszystkich rodzajach budynków współczynnik przepuszczalności energii całkowitej promieniowania słonecznego okien oraz przegród szklanych i przezroczystych g liczony według wzoru:

gdzie:

$$
g=f_{c} \cdot g_{n}
$$

$g_{n}$ - współczynnik całkowitej przepuszczalności energii promieniowania słonecznego dla typu oszklenia,

$\mathrm{f}_{\mathrm{c}}$ - współczynnik redukcji promieniowania ze względu na zastosowanie urządzenia przeciwsłoneczne,

w okresie letnim nie może być większy niż 0,35.

Wartości współczynnika całkowitej przepuszczalności energii promieniowania słonecznego dla typu oszklenia $g_{n}$ oraz warłości współczynnika redukcji promieniowania ze względu na zastosowane urządzenia przeciwsłoneczne $f_{c}$ należy przyjmować na podstawie deklaracji właściwości użyłkowej okna lub przyjmować na podstawie tabeli w załączniku 2 rozporzadzenia ${ }^{18}$.

Przegrody przezroczyste pełnia wiele złożonych i znaczących funkcji. Stanowią bardzo ważny element budynku w aspekcie architektonicznym, jak i technicznym. Analizując wiele projektów i realizacji budynków jednorodzinnych, można zauważyć, że stolarka okienna stanowi ok. 20\% powierzchni ściany zewnętrznej, co powoduje, że izolacyjność cieplna budynku jest ok. 5 razy niższa (wartości gra-

\footnotetext{
15 K. Pawłowski, op. cit.

16 Ibidem.

17 Ibidem.

18 Ibidem.
} 
niczne współczynników przenikania ciepła wg rozporzadzenia ${ }^{19}$ od 31.12.2020 r. $\left.\mathrm{U}_{\text {ściany }}=0,20 \mathrm{~W} /\left(\mathrm{m}^{2} \cdot \mathrm{K}\right), \mathrm{U}_{\text {okna }}=0,90 \mathrm{~W} /\left(\mathrm{m}^{2} \cdot \mathrm{K}\right)\right)$. Tego typu przegrody, szczególnie w budynku o niskim zużyciu energii (NZEB), stanowią integralna część bilansu energetycznego (bilansu zysków i strat ciepła). Dokonanie optymalnego wyboru rozwiązania materiałowego przegród przeźroczystych jest niezwykle ważne i istotne zarówno na etapie planowania, projektowania, jak i budowy-dotyczy wszystkich uczestników procesu inwestycyjnego.

Dachy zielone jako rozwiqzanie architektoniczne było już znane w starożytnym Rzymie, Grecji oraz Babilonii. Przykładem takiego dachu sa Wiszace ogrody Semiramidy (uznawane jako jeden z cudów świata). Kolejne zastosowanie dachów zielonych można zauważyć w XVII-wiecznej Francji, gdzie ogród zielony został zbudowany na stropie oranżerii w południowym skrzydle pałacu wersalskiego. Pełnił on funkcję zwiększenia szczelności pokrycia dachowego oraz poprawiał kompozycje założenia pałacowo-ogrodowego. XIX-wieczne Prusy wykorzystywały dachy zielone do poprawy parametrów przeciwpożarowych budynków2021.

Od drugiej połowy XX wieku zainteresowanie dachami zielonymi wzrasta zarówno w Europie, jaki i Polsce, co wynika z rosnacej świadomości ekologicznej człowieka. Wzrost zastosowania dachów zielonych wiąże się z chęcia poprawy jakości środowiska miejskiego.

Dach zielony to stropodach w systemie odwróconym, stosowany najczęściej na terenach zurbanizowanych. Jego wierzchnia warstwa pozwala na komponowanie na powierzchni dachu zróżnicowanej roślinności. Pełni on wszystkie funkcje dachu konwencjonalnego. Różni się od niego układem warstw, które daja możliwość zastosowania na jego powierzchni różnorodnej roślinności. Ogród taki można zakładać na dachach o pochyleniu połaci od 5\% do 35\%. Należy jednak pamiętać, że przy nachyleniu większym niż $20^{\circ}$ dach taki trzeba zabezpieczać przed osuwaniem się powierzchni gruntowej z połaci. Dach zielony chroni budynek przed czynnikami zewnętrznymi, tj. opadami atmosferycznymi, zmianami temperatur, wiatrem ${ }^{2223}$. Jest przykładem przegrody zewnętrznej wpływającej na obniżenie wskaźników zapotrzebowania na energię w budynku.

Sa trzy rodzaje zazielenienia dachu: ekstensywne, intensywnie niskie, intensywni wysokie. Ich zastosowanie zależy od grubości warstwy wegetacyjnej i zastosowanej na niej roślinności.

Przy powierzchni dachu zielonego min. $10 \mathrm{~m}^{2}$ 50\% †ej wartości uwzględnia się jako teren biologicznie czynny. Bierze on udział w obliczeniu wskaźnika terenów zielonych ${ }^{24}$. Porowata struktura układu dachu zielonego i zastosowana roślinność pochłania i odbija fale dźwiękowe, co korzystnie wpływa na parametry użyłkowe

\footnotetext{
19 Ibidem.
}

${ }^{20}$ B. Sokołowska, 2007. Dachy zielone w aspekcie ekologiczno- technicznym. [W:] Budownictwo ogólne, zagospodarowanie konstrukcyjne, materiałowe i cieplno-wilgotnościowe w budownictwie, Wydawnictwa Uczelniane Uniwersytetu Technologiczno-Przyrodniczego w Bydgoszczy, Bydgoszcz.

21 J. Ślusarek, 2010. Rozwiqzania strukturalno-materiałowe balkonów, tarasów i dachów zielonych. Wydawnictwo Politechniki Śląkiej, Gliwice.

22 L. Lichałai, 2008. Elementy budynków, podstawy projektowania, Budownictwo ogólne tom 3. Wydawnictwo Arkady, Warszawa.

23 J. Mikoś, 1969. Budownictwo ekologiczne. Wydawnictwo Politechniki Śląskiej, Gliwice.

${ }^{24}$ S. Rutkowski, 1975. Planowanie przestrzenne obszarów wypoczynkowych w strefie dużych miast. PWN, Warszawa. 
pomieszczenia ostatniej kondygnacji (zmniejszenie poziomu hałasu ${ }^{25}$. Na rysunku 6 przedstawiono przykładowe rozwiqzanie konstrukcyjno-materiałowe dachu zielonego.

Zastosowanie paneli fotowoltaicznych na dachu zielonym podnosi efektywność działania instalacji solarnych ${ }^{26}$. Jest to korzystne ze względu na efekt synergii przy wytwarzaniu pradu - stosunkowo niska temperatura powierzchni zazielenionej (w porównaniu z dachami tradycyjnymi) prowadzi do mniejszego nagrzewania modułów fotowoltaicznych, co poprawia sprawność modułów. Zastosowanie paneli fotowoltaicznych na dachach zielonych ma też zalety techniczne, system warstw dachu zielonego pełni rolę kotwiąca stabilizuje panele fotowoltaiczne nawet w przypadku silnego wiatru i burz. Konstrukcje wsporcze pod panele można więc montować bez konieczności przebijania warstwy izolacji wodochronnej ${ }^{27}$. Na rysunku 7 przedstawiono przykładowe rozwiqzanie konstrukcyjno-materiałowe słonecznego (solarnego) dachu zielonego.

Słoneczne dachy zielone maja pomagać obszarom, które potrzebują więcej energii. Okazuje się, że zainstalowanie paneli solarnych na dachach zielonych, porośniętych roślinnościa, podnosi efektywność instalacji fotowoltaicznej, a tym samym całego budynku.

Współczesne konstrukcje ścian zewnętrznych moga być projektowane jako fasady wentylowane,

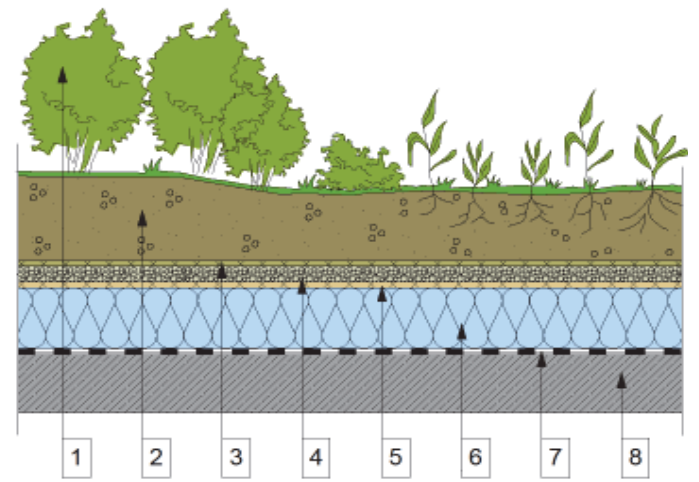

Rys. 6. Elementy struktury dachu zielonego założonego na bazie stropodachu o odwróconej kolejności warstw: 1 - warstwa wegetacyjna, 2 - mata filtrujaco-drenująca, 3 - warstwa drenażowa, 4 - warstwa ochronna, 5 - warstwa termoizolacji, 6 - warstwa hydroizolacyjna, 7 - warstwa konstrukcyjna, strop nad ostatnia kondygnacja (opracowanie własne)

Fig. 6. Green roof system laid onto the flat roof the invited sequence of layers 1 - vegetation layer, 2 - filtering-draining mat, 3 - drainage layer, 4 - protective layer, 5 - insulation layer, 6 - waterproof layer, 7 - construction layer, ceiling above last tier (own study)

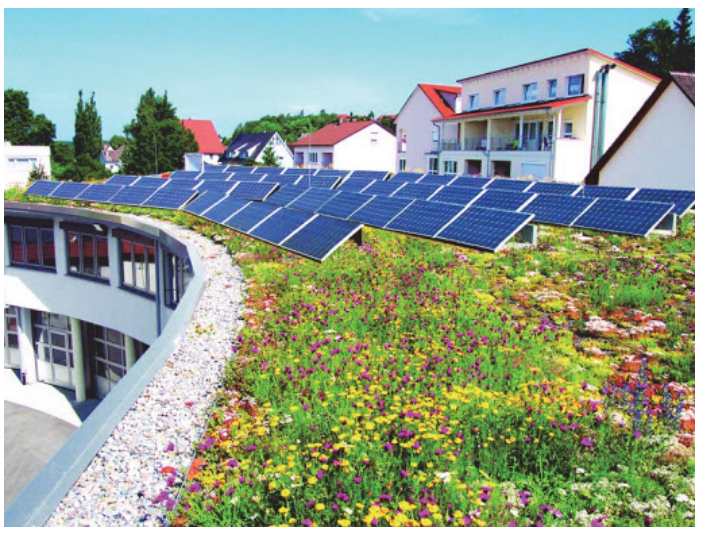

Rys. 7. Przykładowe rozwiązanie konstrukcyjno-materiałowe słonecznego dachu zielonego z zastosowaniem paneli fotowoltaicznych (źródło: Optigruen International AG)

Fig. 7. An example of structural and material solution of a green roof with solar panels (source: Optigruen International AG)

\footnotetext{
25 Ibidem.

${ }^{26}$ FLL, DAFA, „Wyłyczne dla dachów zielonych. Wyłyczne do projektowania, wykonywania i utrzymania dachów zielonych", 2020.

${ }^{27}$ P. Wolański, K. Wolańska, 2020. Słoneczne dachy zielone. Czasopismo Izolacje. 4, s. 60-63.
} 
w których występuja wewnątrz szczeliny powietrzne, odprowadzające nadmierna wilgoć poza przegrodę. Fasady wentylowane moga być wykonane w dwóch technologiach:

- technologia lekka - sucha (montaż elewacji z sidingu, płył włókno-cementowych, płył cementowych, laminatów, elementów drewnianych, blachy aluminiowej itp.),

- technologia ciężka - sucha (ciężkie płyły kamienne lub płyty z kruszywa kamiennego spojonego żywica).

Obie technologie moga spełniać kryterium rozwiązania energooszczędnego - zarówno przy realizacji nowych budynków, jak i przy termorenowacji budynków już istniejacych. Stosowanie tych technologii nie ma praktycznie ograniczeń temperaturowych dotyczacych procesu technologicznego, ponieważ nie wykonuje się prac mokrych na budowie. Szczegółowa charakterystykę rozwiązań konstrukcyjno-materiałowych fasad wentylowanych przedstawiono w pracy K. Schabowicza ${ }^{28}$.

\section{PODSUMOWANIE I WNIOSKI}

Projektowanie, wykonywanie i eksploałacja budynków o niskim zużyciu energii (NZEB) to proces złożony, wymagajacy znajomości wielu zagadnień w zakresie materiałów budowlanych, budownictwa ogólnego, fizyki budowli, instalacji budowlanych, systemów odnawialnych źródeł energii oraz projektowania architektonicznego. W pracy przedstawiono tylko wybrane aspekty w tym zakresie. Na podstawie przeprowadzonych analiz można sfomułować następujące wnioski końcowe.

Projektowanie cieplne przegród zewnętrznych i złączy budynków o niskim zUżyciu energii (NZEB) wymaga indywidulanego podejścia z uwzględnieniem wytycznych i przepisów prawnych. Osiagnięcie wartości współczynnika przenikania ciepła Uc/U [W/( $\left.\left.\mathrm{m}^{2} \cdot \mathrm{K}\right)\right]$ poniżej wartości granicznej polega na poprawnym usytuowaniu materiału termoizolacyjnego oraz określeniu jego odpowiedniej grubości.

Wszystkie kryteria oceny stolarki okiennej powinny być uwzględniane na etapie planowania i projektowania budynków w aspekcie architektoniczno-technicznym, ponieważ wpływają one na mikroklimat wnętrza i komfort użyłkowy budynku, a tym samym na koszty eksploatacyjne. Znaczne powierzchnie przeszklone należy usyłuować na elewacjach południowych lub południowo-wschodnich. Jednak należy pamiętać o zabezpieczeniach w zakresie przegrzewania pomieszczeń w okresie letnim, stosując powłoki na zewnętrznej powierzchni szyb zespolonych, a także rolet lub żaluzji wewnątrz pomieszczenia czy markiz, łamaczy światła, okiennic na zewnątrz budynku. Bardzo istotnym aspektem projektowym i wykonawczym jest poprawne osadzenie stolarki okiennej w ścianie zewnętrznej (poprawne zaprojektowanie i wykonanie złącza dwóch przegród: ściana - okno). Np. w ścianie dwuwarstwowej przedłużenie warstwy izolacji cieplnej na ościeżnicę powoduje zmniejszenie strat ciepła oraz minimalizowanie ryzyka występowania krytycznej wilgotności powierzchniowej (rozwoju pleśni i grzybów pleśniowych na wewnętrznej powierzchni przegrody) na styku okno - ściana zewnętrzna.

Zastosowanie w budynkach nowoczesnych rozwiązań materiałowych dachów zielonych, słonecznych dachów zielonych, ścian zielonych czy też fasad

\footnotetext{
${ }^{28}$ K. Schabowicz, 2018. Elewacje wentylowane. Technologia produkcji i metody badania płył włóknisto-cementowych. Oficyna Wydawnicza Politechniki Wrocławskiej, Wrocław.
} 
wentylowanych pozwala na ograniczenie strat ciepła przez przenikanie, ale także na obniżenie energochłonności budynku. W efekcie końcowym można uzyskać niskie wartości wskaźników: zapotrzebowania na energię użyłkowa EU $\left[\mathrm{kWh} /\left(\mathrm{m}^{2} \cdot \mathrm{rok}\right)\right]$, zapotrzebowania na energię końcowa EK [kWh/( $\left.\left.\mathrm{m}^{2} \cdot \mathrm{rok}\right)\right]$ i zapotrzebowania na nieodnawialna energię pierwotna EP $\left[\mathrm{kWh} /\left(\mathrm{m}^{2}\right.\right.$ rok)] i gwarantuje spełnienie wymagań dla budynku o niskim zużyciu energii (NZEB).

\section{LITERATURA}

[1] FLL, DAFA, Wytyczne dla dachów zielonych. Wytyczne do projektowania, wykonywania i utrzymania dachów zielonych, 2020.

[2] Lichałai L., 2008. Elementy budynków, podstawy projektowania. Budownictwo ogólne. Tom 3, Wydawnictwo Arkady, Warszawa.

[3] Mikoś J., 1969. Budownictwo ekologiczne. Wydawnictwo Politechniki Śląkiej, Gliwice.

[4] Pawłowski K., 2016. Projektowanie przegród zewnętrznych w świetle aktualnych warunków technicznych dotyczacych budynków. Obliczenia cieplno-wilgotnościowe przegród zewnętrznych i ich złączy. Grupa Wydawnicza Medium, Warszawa.

[5] PN-EN ISO 6946:2008 Komponenty budowlane i elementy budynku. Opór cieplny i współczynnik przenikania ciepła. Metoda obliczania.

[6] PN-EN ISO 10211:2008 Mostki cieplne w budynkach. Strumienie ciepła i temperatury powierzchni. Obliczenia szczegółowe.

[7] PN-EN ISO 13788:2003 Cieplno-wilgotnościowe właściwości komponentów budowlanych i elementów budynku. Temperatura powierzchni wewnętrznej umożliwiajaca uniknięcie krytycznej wilgotności powierzchni wewnętrznej kondensacji. Metody obliczania.

[8] PN-EN ISO 14683:2008 Mostki cieplne w budynkach. Liniowy współczynnik przenikania ciepła. Metody uproszczone i wartości orientacyjne.

[9] Rozporządzenie Ministra Infrastruktury i Budownictwa z dnia 14 listopada 2017 r. zmieniajace rozporzadzenie w sprawie warunków technicznych, jakim powinny odpowiadać budynki i ich usytuowanie (Dz.U. z 2017 r. poz. 2285).

[10] Rozporzadzenie Ministra Infrastruktury i Rozwoju w sprawie metodologii obliczania charakterystyki energetycznej budynku i lokalu mieszkalnego lub części budynku stanowiącej samodzielna całość techniczno-użytkowa oraz sposobu sporzadzania i wzorów świadectw charakterystyki energetycznej (Dz.U. z 2015 r., poz. 376).

[11] Rutkowski S., 1975. Planowanie przestrzenne obszarów wypoczynkowych W strefie dużych miast. PWN, Warszawa.

[12] Schabowicz K., 2018. Elewacje wentylowane. Technologia produkcji i metody badania płył włóknisto-cementowych. Oficyna Wydawnicza Politechniki Wrocławskiej, Wrocław.

[13] Sokołowska B., 2007. Dachy zielone w aspekcie ekologiczno-łechnicznym. [W:] Budownictwo ogólne, zagospodarowanie konstrukcyjne, materiałowe i cieplno-wilgotnościowe w budownictwie, Wydawnictwo Uczelniane Uniwersytetu Techniczno-Przyrodniczego w Bydgoszczy, Bydgoszcz.

[14] Ślusarek J., 2010. Rozwiązania strukturalno-materiałowe balkonów, tarasów i dachów zielonych. Wydawnictwo Politechniki Śląskiej, Gliwice. 
[15] Uchwała Rady Ministrów z dnia 22 czerwca 2015 r. w sprawie przyjęcia „Krajowego planu mającego na celu zwiększenie liczby budynków o niskim zużyciu energii".

[16] Ustawa z dnia 7 lipca 1994 r. - Prawo budowlane (Dz.U. z 2013 r. poz. 1409, z późn. zm.).

[17] Wesołowska M., Pawłowski K., 2016. Aspekły zwiqzane z dostosowaniem obiektów istniejących do standardu budownictwa energooszczędnego. Agencja Reklamowa TOP, Włocławek.

[18] Wolański P., Wolańska K., 2020. Słoneczne dachy zielone. Czasopismo Izolacje 4, s. 60-63.

\section{BUDYNKI O NISKIM ZUŻYCIU ENERGII (NZEB) W ASPEKCIE ARCHITEKTONICZNO-BUDOWALNYM}

STRESZCZENIE. Projektowanie, wykonanie i eksploatacja budynków o niskim zużyciu energii (NZEB) jesł procesem złożonym, wymagającym znajomości interdyscyplinarnych zagadnień w zakresie: projektowania architektonicznego, materiałów budowanych, budownictwa ogólnego, fizyki budowli oraz instalacji budowlanych z zastosowaniem odnawialnych źródeł energii (OZE). W pracy przedstawiono podstawy prawne oraz charakterystykę budynków o niskim zużyciu energii (NZEB) w aspekcie architektoniczno-budowlanym. Realizacja obowiazujacych wymagań prawnych polega na sprawdzeniu wielu parametrów całego budynku, a w szczególności jego przegród zewnętrznych i ich złączy oraz instalacji budowlanych. Dlatego w pracy zaprezentowano obliczenia w zakresie kształtowania układów materiałowych przegród zewnętrznych i złączy budowlanych przy zastosowaniu profesjonalnych programów komputerowych. Integralna częścia artykułu jest identyfikacja czynników wpływających na energochłonność budynku o niskim zużyciu energii (NZEB) w aspekcie architektoniczno-budowlanym.

Słowa kluczowe: przegrody zewnętrzne, energochłonność budynku, budynek o niskim zużyciv energii

\section{BUILDINGS WITH LOW ENERGY CONSUMPTION IN THE ARCHITECTURAL AND CONSTRUCTION ASPECT}

SUMMARY. The design, erection and operation of buildings with low energy consumption is a complex process that requires knowledge of multidisciplinary issues in the field of: architectural design, building materials, general construction, building physics and building systems using renewable energy sources (RES).

The paper presents legal bases and characteristics of buildings with low energy consumption in the architectural and construction aspect. The implementation of applicable legal requirements involves checking a number of factors relating to a building, in particular external walls, wall joints as well as building systems. Therefore this article presents calculations regarding different material arrangements for external walls and building joints with the use of professional computer software. An integral part of the article is the identification of factors affecting the energy consumption of a building with low energy consumption in the architectural and construction aspect.

Key words: external partitions, building energy consumption, building with low energy consumption 